Marcin Drąg OFMConv, Rozwój przestrzeni liturgicznej kościołów franciszkańskich od XIII do XVIII wieku, w: Przestrzeń liturgiczna, red. Adelajda Sielepin CHR, Jarosław

Superson SAC, Kraków 2019, s. 75-99.

DOI: http://dx.doi.org/10.15633/9788374387828.05

\title{
Marcin Drąg OFMConv
}

Uniwersytet Papieski Jana Pawla II w Krakowie

\section{Rozwój przestrzeni liturgicznej kościołów franciszkańskich od XIII do XVIII wieku}

Jeden z fresków bazyliki św. Franciszka w Asyżu przedstawia założyciela braci mniejszych jako podtrzymującego gmach kościoła. Malowidło wielkiego włoskiego artysty - Giotta - nawiązuje do snu papieża Innocentego III, w którym pokorny zakonnik na swoich ramionach wspiera chylącą się ku upadkowi bazylikę św. Jana na Lateranie. Wizja ojca świętego okazała się prorocza, gdyż niedługo po tym wydarzeniu przybył do niego św. Franciszek, prosząc o zatwierdzenie reguły nowo powstałej wspólnoty. Swoją szeroko pojętą działalnością przyczyniła się ona do odnowy życia Kościoła, będącego w okresie średniowiecza w głębokim kryzysie ${ }^{\mathrm{I}}$.

Związanie osoby założyciela minorytów z bazyliką laterańską miało swoją kontynuację w sprawowaniu liturgii przez nowo powstały zakon, ponieważ naśladowcy św. Franciszka zostali zobowiązani na mocy reguły do celebracji służby Bożej według zwyczajów kurii rzymskiej². Wybór tej tradycji liturgicznej gwarantował wierność Kościołowi oraz jedność wewnątrz wspólnoty. Uroczyście sprawowana liturgia w kościołach franciszkańskich była centrum dokonującej się odnowy życia duchowego wiernych, przyczyniła się też do ekspansji zakonu. W ten sposób symboliczny sen papieża Innocentego w ciągu kolejnych stuleci realizował się w działaniach synów św. Francisz-

I Por. Relacja Trzech Towarzyszy, w: Źródła franciszkańskie: Pisma Świętego Franciszka. Źródła biograficzne Świętego Franciszka. Pisma Świętej Klary i źródła biograficzne. Teksty ustalające normy dla braci i sióstr od pokuty, red. R. Prajs, Z. Kijas, Kraków 2005, s. I49I.

2 Por. J. Pikulik, Franciszkanie nosicielami laterańskiej tradycji liturgiczno-muzycznej, „Studia Theologica Varsaviensia” 25 (I987) nr I, s. 6. 
ka na rzecz jakości sprawowanego kultu, rozwoju teologii, filozofii, kultury i sztuki sakralnej

Pobożność braci, kształtowana przez liturgię, regułę, pisma autorów franciszkańskich i samego założyciela stwarzała coraz to nowe formy wyrażania duchowości, zawsze jednak w posłuszeństwie Stolicy Apostolskiej. Potwierdzeniem tego posłuszeństwa stawały się przywileje, jakie zakon otrzymywał na kanwie życia liturgicznego, począwszy od ustanowienia kościołów Braci Mniejszych konwentualnymi, przez wprowadzanie własnych świąt i zwyczajów, aż do przyjęcia przez Kościół rzymski liturgii franciszkańskiej

Celem niniejszej publikacji jest ukazanie zmian zachodzących w przestrzeni sakralnej zajmowanej przez franciszkanów. Autor przyjął jako dolną granicę czasową wiek powstania wspólnoty minorytów, natomiast jako górną granicę wiek XVIII. Ramy czasowe wyznaczone w artykule pozwolą na dokładniejszą analizę dokumentów zakonnych, źródeł i opracowań. Metoda historyczna przyjęta w niniejszej publikacji pozwoli znaleźć odpowiedź na pytania: Jak przebiegały zmiany w przestrzeni liturgicznej franciszkańskich świątyń? Co wpływało na ewolucję wnętrz kościołów minorytów?

Pierwsza część pracy ukazuje świątynię franciszkańską jako miejsce sprawowania liturgii przez pierwotną wspólnotę minorytów, gdzie punktem wyjścia są wskazania św. Franciszka odnoszące się do kościołów, powierzonych opiece braci. Następnie, na podstawie najstarszych przepisów liturgicznych braci mniejszych, zostanie przedstawione wnętrze typowych świątyń minoryckich w epoce średniowiecza. Kolejna część artykułu jest analizą oficjalnych dokumentów Zakonu Braci Mniejszych Konwentualnych, traktujących o liturgii i przestrzeni sakralnej.

\section{ŚWIĄTYNIA - MIEJSCE MODLITWY ŚW. FRANCISZKA I WSPÓLNOTY MINORYTÓW}

Sen papieża Innocentego III, w którym pokorny zakonnik podtrzymuje chylący się ku upadkowi kościół, znalazł realizację nie tylko w rzeczywistości duchowej,

\footnotetext{
3 Por. F. Costa, Impegno ecclesiale dei Frati Minori Conventuali nella cultura ieri e oggi (I209-1997), a cura di F. Costa, Roma I998.

4 Por. J. Pikulik, Franciszkanie nosicielami..., dz. cyt., s. II.
} 
ale również materialnej. Święty Franciszek w początkach swojego nawrócenia przebywał w popadających w ruinę kościołach leżących w okolicach Asyżu. Źródła franciszkańskie potwierdzają, że zajmował się ich odbudową. Inspirację do takiej postawy znalazł w głosie Chrystusa, który przemówił doń z krzyża w kościele św. Damiana: „Franciszku, czyż nie widzisz, że ten dom mój chyli się ku upadkowi? Idź więc i napraw go"s. Troska o świątynię materialną przerodziła się w umiłowanie Kościoła duchowego, pojmowanego przez założyciela braci mniejszych jako Matka: „Chcę, by moi bracia okazywali się synami tej samej Matki"6.

Odnawiana przestrzeń kościołów Asyżu staje się miejscem wzrostu pierwszej wspólnoty franciszkańskiej. Święty Franciszek w Testamencie wyraźnie podkreśla rolę świątyni w pierwszym etapie rozwoju braterskiej wspólnoty: „I Pan dał mi w kościołach taką wiarę, że tak po prostu modliłem się i mówiłem: «Wielbimy Cię, Panie Jezu Chryste, tu i we wszystkich kościołach Twoich, które są na całym świecie i błogosławimy Tobie, że przez święty krzyż Twój odkupiłeś świat»" M. Mimo że młody zakon nie posiadał jeszcze kościołów, to bracia, nawiedzając napotkane świątynie, odnajdywali w nich swoje miejsce modlitwy. Przestrzeń sakralna stawała się środowiskiem wzrostu wiary minorytów i okazją do uwielbienia Chrystusa za dar odkupienia, którego średniowieczne kościoły w swojej architekturze i symbolice są znakiem8.

Najstarsze źródła franciszkańskie nie podają żadnych szczegółowych informacji na temat przestrzeni liturgicznej miejsc zajmowanych przez franciszkanów. Centralnym ośrodkiem gromadzenia się pierwszych towarzyszy św. Franciszka został mały kościółek Matki Bożej Anielskiej, podarowany wspólnocie braci przez benedyktynów z Monte Subasio ${ }^{9}$. Ubóstwo tego miejsca z pewnością wpisywało się w ideę św. Franciszka, by bracia „nie przyjmowali kościołów, ubogich mieszkań i wszystkiego, co się dla nich buduje, jeśli się to nie zgadza ze świętym ubóstwem"ঙo

Kryterium obejmowania kościołów przez minorytów stało się ubóstwo, które miało cechować ich architekturę i strukturę. Z drugiej strony założyciel

\footnotetext{
5 Relacja Trzech Towarzyszy..., dz. cyt., s. I466.

6 Brat Tomasz z Celano, Życiorys drugi Świętego Franciszka z Asyżu, w: Źródła franciszkańskie..., dz. cyt., s. 696.

7 Testament, w: Pisma św. Franciszka i św. Klary, tłum. o. K. Ambrożkiewicz, red. M. Macioszek, E. Szelachowski, P. Brzozowska, Warszawa I992, s. 68.

8 Por. D. Forstner, Świat symboliki chrześcijańskiej, Warszawa I990, s. 27 I.

9 Por. L. Iriarte, Historia franciszkanizmu, Kraków I998, s. 29.

io Testament..., dz. cyt., s. 68.
} 
franciszkanów, ze względu na wielką cześć wobec tajemnicy Eucharystii nakazuje braciom w Liście do kustoszów: „I jeśli w jakimś miejscu Najświętsze Ciało Pana będzie umieszczone za ubogo, niech będzie według przepisów Kościoła umieszczone przez nich w miejscu godnym i zabezpieczone, i niech je noszą z wielką czcią, i roztropnie udzielają innym" ".

Przepis wyraźnie wskazuje na to, że zasada ubóstwa nie obowiązuje miejsca, w którym przechowywany jest Najświętszy Sakrament. List do kustoszów zredagowany ok. I220 roku z pewnością był napisany pod wpływem nauczania Soboru Laterańskiego IV (I2I5). Postanowienie soboru odnoszące się do miejsca przechowywania Świętych Postaci nakazuje, aby we wszystkich kościołach krzyżmo i Eucharystia były strzeżone wiernie, pod zamknięciem, by nie dochodziło do bezbożnych zachowań wobec tego, co święte ${ }^{12}$. Dokument soborowy nie określał dokładnego miejsca przechowywania Sanctissimum. Według papieża Honoriusza III miejsce to powinno być czyste i wyróżniające się. Eucharystię w okresie średniowiecza przechowywano na ołtarzu lub w niszy ściany prezbiterium. Miejsca te nazywano armarium, sacrarium, custodia. Armaria z jednej strony zapewniały bezpieczeństwo w przechowywaniu Najświętszego Sakramentu, z drugiej miały się wyróżniać. Dlatego też armarium było przyozdabiane i z czasem coraz bardziej eksponowane ${ }^{13}$. Franciszek, idąc za poleceniami Kościoła, nakazuje, by wszystko, co jest związane z Eucharystią, było kosztowne: „Kielichy, korporały, ozdoby ołtarza i wszystko, co służy do Ofiary, niech będą kosztowne"It.

Znamienny dla założyciela franciszkanów jest szczególny kult Eucharystii. Troska o właściwe miejsce sprawowania służby Bożej oparta jest na głębokim przekonaniu co do obecności Chrystusa pod świętymi postaciami, które św. Franciszek niemal jak refren podkreślał w swoich pismach: „Całując wam stopy, błagam was wszystkich, bracia, z taką miłością na jaką mnie stać, abyście tak jak tylko możecie, okazywali wszelkie uszanowanie i wszelką cześć Najświętszemu Ciału i Krwi Pana naszego Jezusa Chrystusa, w którym to, co jest w niebie i to, co jest na ziemi, zostało obdarzone pokojem i pojednane z Wszechmogącym Bogiem"'5. W centrum pierwotnej świątyni francisz-

\footnotetext{
I List do kustoszów (I), w: Pisma św. Franciszka i św. Klary, dz. cyt., s. I07.

I2 Por. Sobór Laterański IV, w: Dokumenty soborów powszechnych, t. 2, oprac. A. Baron, H. Pietras, Kraków 2003, s. 259.

I3 Por. Leksykon liturgii, oprac. B. Nadolski, Poznań 2005, s. I556-I557.

${ }^{14}$ List do kustoszów (I), dz. cyt., s. I07.

I5 List skierowany do całego Zakonu, w: Pisma św. Franciszka i św. Klary, dz. cyt., s. 98.
} 
kańskiej, jak również całej wspólnoty braterskiej jest Chrystus w tajemnicy Eucharystii której bracia mają okazywać najwyższą cześć.

Szczególną uwagę św. Franciszek zwraca na wspólnie celebrowaną ofiarę mszy świętej. „Dlatego upominam i zachęcam w Panu, aby w miejscach, gdzie przebywają bracia, była odprawiana w ciągu dnia tylko jedna Msza Święta według przepisów Kościoła świętego. Jeśli zaś jest na miejscu więcej kapłanów, niech jeden zadowoli się z miłości uczestnictwem [we Mszy] odprawianej przez drugiego kapłana; bo Pan Jezus Chrystus napełnia obecnych i nieobecnych, którzy są tego godni. Chociaż Go widać w wielu miejscach, pozostaje jednak niepodzielny i nie doznaje żadnego uszczerbku, lecz jeden działa wszędzie, jak Mu się podoba, z Panem Bogiem Ojcem i z Duchem Świętym Pocieszycielem na wieki wieków. Amen"'16. Instrukcja św. Franciszka była pewnym novum, ze względu na popularne msze prywatne, sprawowane w klasztorach przez wszystkich kapłanów osobno ${ }^{17}$. Msza celebrowana we wspólnocie braci stawała się ściśle konwentualną, gromadzącą członków wspólnoty przy jednym ołtarzu.

Reguła napisana przez św. Franciszka nakazywała, by bracia sprawowali oficjum według przepisów świętego Kościoła rzymskiego. Dlatego oprócz centralnego miejsca we franciszkańskiej świątyni, którym był ołtarz oraz miejsce przechowywania Najświętszego Sakramentu, należy wyszczególnić przestrzeń sprawowania oficjum. Pisma św. Franciszka oraz Wczesne źródta franciszkańskie nie podają żadnych instrukcji odnośnie do miejsca sprawowania liturgii godzin. $Z$ treści Testamentu możemy przypuszczać, że sprawowano ją w kościołach i była regularnie celebrowana już za życia św. Franciszka: „Oficjum odmawialiśmy my, klerycy, jak inni duchowni; nieklerycy odmawiali: Ojcze nasz; i bardzo chętnie przebywaliśmy w Kościołach"זr8. Pomimo początkowo wędrownego charakteru wspólnoty, miejsce sprawowania liturgii było związane z przestrzenią sakralną.

Według św. Franciszka bracia są przede wszystkim przeznaczeni do służby Bożej, która obejmowała nie tylko sprawowanie liturgii czy opiekę nad ludźmi najbardziej odrzucanymi przez ówczesne społeczeństwo. W przekonaniu założyciela minorytów ich misja sięga o wiele dalej: „A ponieważ kto z Boga jest, słucha słów Bożych (J 8, 47), my, którzy jesteśmy specjalnie przeznaczeni do służby Bożej, powinniśmy nie tylko słuchać i czynić to, co mówi Bóg, lecz

\footnotetext{
I6 List skierowany do całego Zakonu, dz. cyt., s. Ioo.

${ }_{17}$ Por. M. Kunzler, Liturgia Kościoła, Poznań 1995, s. 302.

I8 Testament..., dz. cyt., s. 68.
} 
także strzec naczyń [liturgicznych] oraz wszystkich ksiąg, które zawierają święte słowa Boże"'. . Bracia stają się kustoszami wszystkiego, co święte. To zadanie z pewnością wymagało organizacji odpowiednich pomieszczeń, w których paramenty liturgiczne i księgi mogły być godnie przechowywane. Intuicje św. Franciszka miały swoje następstwo w dynamicznym rozwoju przestrzeni liturgicznej użytkowanej przez minorytów.

\section{EWOLUCJA ŚWIĄTYŃ FRANCISZKAŃSKICH: OD ORATORIUM WSPÓLNOTY DO KOŚCIOLA KONWENTUALNEGO}

Reguła zakonu św. Franciszka została zatwierdzona przez papieża Honoriusza III w I223 roku. Dokument zawierał zasadnicze rysy charyzmatu zakonodawcy oraz nowe przepisy strukturalne dotyczące organizacji życia wspólnoty liczącej ok. 5 tysięcy braci. Minoryci, przeżywający ekspansję misyjną do krajów zaalpejskich oraz na Bliski Wschód opanowany przez muzułmanów, przeobrażają się w wielki organizm, podzielony na prowincje i jednostki klasztorne. Prężne życie wspólnoty skupia się na wędrówkach misyjnych, pracy rąk własnych, kaznodziejstwie wędrownym oraz sprawowaniu kultu w kościołach powierzanych opiece synów św. Franciszka. Początkowo są to małe kościółki i pustelnie poza murami miast, a następnie w centrach średniowiecznych aglomeracji ${ }^{20}$.

Świątynie będące pod opieką franciszkanów w głównej mierze pełniły funkcję oratoriów wspólnoty, celebrującej liturgię. Pierwsze dokumenty Stolicy Apostolskiej obejmujące kościoły franciszkańskie dotyczyły sprawowania Oficium divinum oraz mszy świętej. Papież Honoriusz III w bulli Devotionis vestrae z I222 roku udzielił braciom indultu zezwalającego na modlitwę oficjum, nawet w trakcie interdyktu generalnego. Jednak nakazal, by w takiej sytuacji modlili się z należną ostrożnością i półgłosem. Papież wspomina, że gdyby braciom zdarzyło się posiadać kościoły, należy to czynić przy drzwiach zamkniętych, z daleka od ekskomunikowanych. Kolejny dokument Mira circa nos z I224 roku tego samego papieża zezwalał już otwarcie

\footnotetext{
I9 List skierowany do całego Zakonu, dz. cyt., s. Ioo.

20 Por. W. Di Fonzo, J. Odoardi, A. Pompei, Bracia mniejsi konwentualni. Historia i życie I209-I976, Niepokalanów I988, s. 40-46, 90.
} 
na celebrację „uroczystych Mszy oraz innych oficjów Bożych w miejscach i oratoriach, gdzie przechowuje się Najświętszy Sakrament"ı.

Przełomowym dekretem papieskim stała się bulla Cum tamquam vieri papieża Innocentego IV ogłoszona w I250 roku. Stolica Apostolska ustanowiła wszystkie kościoły franciszkańskie konwentualnymi, co zobowiązywało wspólnoty zamieszkujące przy nich do sprawowania uroczystej liturgii godzin w dzień i w nocy z całą wspólnotą braci ${ }^{22}$. Również msza święta gromadząca konwent, w którym zapewne mieszkali już bracia posiadający różne funkcje i stopnie kapłaństwa, była sprawowana uroczyście ze śpiewem ${ }^{23}$. Ponadto przywileje kościołów konwentualnych obejmowały możliwość udzielania sakramentów, sprawowania pogrzebów oraz używania dzwonów ${ }^{24}$.

Zmiany strukturalne w zakonie wpływały na ewolucję przestrzeni sakralnej użytkowanej przez minorytów. Uroczyście sprawowana liturgia wymagała organizacji chórów i stalli, w których zakonnicy mogli właściwie celebrować oficjum według zwyczaju Kościoła rzymskiego. Istnienie stalli poświadczają statuty liturgiczne zwane Ordinationes zatwierdzane na kapitułach generalnych zakonu ${ }^{25}$. Jeden ze statutów tak opisuje organizację liturgii w klasztorze franciszkańskim w XIII wieku: „W każdym chórze powinno być dwóch kantorów, jeden z jednej strony, drugi z drugiej, którzy rozdzielają poszczególne antyfony dla poszczególnych braci, każdy po swojej stronie. A kantor, który poddaje antyfony, powinien intonować psalm, a po nim sam powinien ją powtórnie rozpoczynać i wówczas powinna być śpiewana wspólnie przez oba chóry. Antyfona przed psalmem nigdy nie powinna być rozpoczynana przez dwóch [kantorów]. Czytania zaś powinny być czytane na środku chóru lub w innym dogodniejszym miejscu. Responsoria nocne i dzienne niech bracia śpiewają w swoich stallach, tak jak antyfony, jeśli mają odpowiednie

${ }^{21}$ Por. J. Norel, Liturgiczna modlitwa godzin we wczesnej tradycji franciszkańskiej, w: Modlitwa franciszkańska, red. C. Napiórkowski, W. Koc, Niepokalanów 200I, s. 325-326.

${ }_{22}$ Por. J. Norel, Liturgiczna modlitwa godzin..., dz. cyt., s. 326.

23 Por. L. Iriarte, Historia ..., dz. cyt., s. I24.

24 Por. W. Di Fonzo, J. Odoardi, A. Pompei, Bracia mniejsi konwentualni ..., dz. cyt., s. 48.

25 Statuty liturgiczne franciszkanów w swojej najbardziej dynamicznej fazie powstawania obejmują lata I245-I263. Podczas kapituł generalnych zatwierdzano nowe zwyczaje liturgiczne, wprowadzano święta własne zakonu, opisywano przebieg ceremonii. Najstarsze dwa manuskrypty zawierające franciszkańskie przepisy liturgiczne to: ms. 338 Bibl. Com. Assisi spisany najprawdopodobniej dla klasztoru Sacro Convento w Asyżu ok. I263 roku oraz ms. Vat. Reg. lat. 429 sporządzony we Francji u schyłku XIII wiku. Por. K. Kaproń, Antiphoniarium Archivi s. Rufini, Assisi, Codex 5, Città del Vaticano 2009, s. 5 I. 
księgi" ${ }^{26}$. Środek chóru był zaopatrzony w pulpit, z którego były podejmowane niektóre części oficjum: „W I niedzielę Adwentu wersety trzech pierwszych responsoriów niech odmawia na przemian trzech kantorów, poczynając od strony hebdomadarza. Podobnie niech odmawiają Gloria Patri, od pulpitu pośrodku chóru"'27.

Przepisy liturgiczne braci mniejszych ukazują przebieg ceremonii oraz odkrywają przed nami sposób użytkowania paramentów liturgicznych: „In festis duplicibus maioribus immediate post secundum pulsationem in utrisque Vesperis et Matutinis sacerdos cum duobus cantoribus, vel quattor in magnis conventibus, superpelliciis indumantur et duo accoliti cum turibulario puperpellicis solummodo induantur, ita quod in principio tertie pulsationis, preparato turibulo, et luminaribus acensis, hoc ordine chorum ingrediantur: primo praecedant cantores, deinde ceroferarii, tertio turibularius dextera manu portans turibulum et sinistra incensum, ultimo sacerdos coram altari procedens. Et stans in medio accolitorum, ponat incensum inturibulo. Quo accepto de manu ministri, genuflectat coram altari et adoleat maius altare tantum"28.

Kościoły franciszkańskie zaopatrzone w dzwony, co potwierdza powyższy fragment Ordinationes, oraz w paramenty konieczne do uroczystego sprawowania liturgii, jak szaty (superpelliciis) czy kadzielnice, stają się z czasem miejscami modlitwy nie tylko braci, lecz także wiernych, co determinuje dalszy rozwój przestrzeni liturgicznej.

Świątynie franciszkańskie jeszcze w XIII wieku ulegają znacznym przeobrażeniom. Kościoły, takie jak Santa Croce we Florencji, Ara Coeli w Rzymie, otrzymują szczególną rangę w Państwie Kościelnym, ze względu na wielkość konwentów, ich strukturę bazylikową i wartość artystyczną ${ }^{29}$. W innych kościołach prowincji przedalpejskich i zaalpejskich wydłuża się chóry zakonne, co było spowodowane liczebnością braci i klerykalizacją zakonu. Przestrzeń zostaje podzielona na dwie części: konwentualną i przeznaczoną dla świeckich. Podział między częścią zarezerwowaną wyłącznie dla zakonników a resztą kościoła akcentowała przegroda, zwana lektorium, służąca za ambonę i miejsce

\footnotetext{
${ }_{26}$ Tłumaczenie własne za K. Kaproń, Antiphoniarium Archivi..., dz. cyt., s. 5I.

27 J. Norel, Liturgiczna modlitwa godzin..., dz. cyt., s. 357.

${ }_{28}$ Ordinationes Divini Offici, 32, za: S. J. P. Van Dijk, Sources of the Modern Roman Liturgy. The Ordinals by Haymo of Faverscham and Related Documents (I243-I307), t. 2, Leiden I963, s. 346.

29 Por. W. Schenkluhn, Architettura degli Ordini Mendicanti, Padova 2003, s. 48-49, I79-178; P. Lomabrdo, G. Passarelli, Ara Coeli: la basilica e il convento: dal XVI al XX secolo attraverso le stampe del fondo della postulazione della Provincia romana dei frati minori, Roma 2003.
} 
ustawienia ołtarza ${ }^{30}$. Cechą charakterystyczną dla świątyń franciszkańskich było umiejscowienie chóru za ołtarzem ${ }^{31}$. Taką strukturę potwierdzają zachowane w swej pierwotnej architekturze najstarsze kościoły franciszkańskie, między innymi w Asyżu, Kortonie i Padwie ${ }^{32}$. Również krakowski kościół św. Franciszka powstały w XIII wieku prawdopodobnie posiadał przestrzeń zorganizowaną według wzorca włoskiego ${ }^{33}$.

Z jednej strony kościoły minorytów otrzymują specjalne przywileje i stają się ważnymi ośrodkami religijnymi, z drugiej kapituły generalne warunkują ich formę wewnętrzną i zewnętrzną ścisłym kryterium ubóstwa. Ważne przepisy w tej materii przekazują dokumenty kapituły w Narbone z I260 roku: „Wymyślność i zbytek bezpośrednio sprzeciwiają się ubóstwu; wobec tego zarządzamy, aby w budowach troskliwie unikano wszelkiego rodzaju wymyślności w malowidłach, ozdobach, oknach, kolumnach i tym podobnych rzeczach oraz wszelkiego zbytku, jeśli chodzi o szerokość, długość i wysokość, uwzględniając warunki danego miejsca. Kościoły bez pozwolenia ministra generalnego, niech nie mają sklepień, za wyjątkiem kaplicy większej (absyda). Odtąd na przyszłość niech nie buduje się dzwonnic przy kościele w formie wieży. Tym bardziej niech się nie umieszcza malowanych witraży, za wyjątkiem witraża głównego w absydzie, za głównym ołtarzem, w który mogą być wprawione wizerunki Chrystusa Ukrzyżowanego, Najświętszej Maryi Panny, św. Jana, św. Franciszka i św. Antoniego"34. Statuty narbońskie jednoznacznie nakreślają styl kościołów franciszkańskich co do architektury oraz wystroju. Na szczególną uwagę zasługuje zapis o witrażach, który w swym przesłaniu ukazuje cechy duchowości młodego jeszcze zakonu. Wizerunek Chrystusa Ukrzyżowanego cechuje pobożność średniowiecza oraz duchowość samego założyciela minorytów, który na cześć Zbawicie-

$3^{3}$ Por. M. Kutzner, Architektura średniowiecznych klasztorów i kościołów franciszkańskich w Polsce, „Acta Universitatis Nicolai Copernici. Zabytkoznawstwo i Konserwatorstwo I3. Nauki Humanistyczno-Społeczne" I989 z. I76, s. 26-27.

$3^{\mathrm{I}} \quad$ Por. J. Superson, Ottarz, krzyż i kierunek zanoszonych modlitw, Kraków 20I4, s. 78.

32 Por. W. Schenkluhn, Architettura..., dz. cyt., s. 40, 66, 77.

33 Por. M. Szyma, In ecclesia sancti Francisci in chori medio. Wprowadzenie do badań nad miejscem chóru liturgicznego w kościołach średniowiecznego Krakowa, w: Średniowieczna architektura sakralna $w$ Polsce $w$ świetle najnowszych badań, red. T. Janiak, D. Stryniak, Gniezno 20I4, s. 265-282.

34 Statuta generalia Ordinis edita in Capitulis generalibus celebratis Narbonae an. I260, Assisi an. I279, atque Parisiis an. I292, red. M. Bihl, „Archivim Franciscanum Historicum” 34 (I94I), s. 48, za: L. Iriarte, Historia ..., dz. cyt., s. I85. 
la skomponował Oficjum o Męce Pańskiej35. Dla św. Franciszka Chrystus cierpiący był znakiem utożsamienia się z człowiekiem, Ukrzyżowanego odkrywał on jako Arcykapłana składającego się w ofierze Ojcu Niebieskie$\mathrm{mu}^{36}$. Najświętsza Maryja Panna otaczana szczególną czcią przez minorytów, od samego początku ich istnienia miała znaczące miejsce w modlitwie wspólnoty, jako opiekunka zakonu ${ }^{37}$. Osobę św. Jana Ewangelisty należałoby odczytać w kluczu pasji Chrystusa, któremu umiłowany uczeń towarzyszy do końca ${ }^{38}$. Związek Chrystusa, Maryi i św. Jana był powszechnie ukazywany w sztuce średniowiecza Kościoła wschodniego i zachodniego jako idea Deesis lub Trina Sanctitas, z tym że w tradycji z osobą św. Jana wiązano św. Jana Chrzciciela. Chrystus przedstawiany był jako Pantokrator, Pan nieba i ziemi, natomiast Maryja i Jan Chrzciciel jako najbardziej uprzywilejowane postaci reprezentujące ludzkość39. Biorąc pod uwagę powyższy fakt, należy uznać, że bardziej prawdopodobną interpretacją osoby św. Jana jest Jan Ewangelista, gdyż to on stał pod krzyżem z Maryją, co przekazuje średniowieczna ikonografia Ukrzyżowanego ${ }^{40}$.

Postać św. Franciszka w przestrzeni liturgicznej kościołów minoryckich wydaje się uzasadniona na podstawie samego faktu założenia zakonu oraz upodobnienia do Chrystusa dzięki otrzymanemu w I224 roku darowi stygmatów. Natomiast św. Antoni, poprzez cuda i sztukę przepowiadania wywarł wielki wpływ nie tylko na życie ówczesnych franciszkanów, ale również na pobożność wiernych, którzy licznie nawiedzali sanktuarium padewskie, aby uczcić jego relikwie ${ }^{4 \mathrm{r}}$.

Konstytucje narbońskie nakreśliły swoisty program przestrzeni sakralnej kościołów franciszkańskich. W centrum tego programu znajduje się Ukrzyżowany Zbawiciel, którego ofiara uobecnia się w tajemnicy mszy świętej. W tej

35 Por. Oficjum o Męce Pańskiej, w: Pisma św. Franciszka i św. Klary, dz. cyt., s. I34.

36 Por. A. Szymański, Św. Franciszek a krzyż, w: Franciszkową droga, red. J. Bar, Warszawa I982, s. 204-205.

37 Od I249 roku franciszkanie dołączyli do codziennej modlitwy liturgicznej śpiew Salve Regina z odpowiednim wersetem i modlitwą. Por. J. Superson, Wersety psalmiczne w ,preces , godzin kanonicznych, Tyniec 2016, s. I93.

${ }^{8}$ Por. A. Szymański, Św. Franciszek..., dz. cyt., s. 205.

39 Por. R. Mazurkiewicz, Deesis, Kraków I994, s. I70-I7I.

40 Idea Trina Sanctitas w Kościele zachodnim łączy się również z Chrystusem Ukrzyżowanym, obok którego stoi Maryja i św. Jan Ewangelista. Taka koncepcja wynikała z pasyjnej pobożności średniowiecza. Zob. R. Mazurkiewicz, Deesis, dz. cyt., s. I34-I35.

${ }_{4 \mathrm{I}} \quad$ Por. R. Manselli, Pierwsze stulecie historii franciszkanów, Kraków 2006, s. 68. 
ofierze uczestniczy Kościół reprezentowany przez Maryję² i św. Jana. Święci Franciszek i Antoni są przedstawicielami ludu odkupionego krwią Chrystusa, którzy idąc Jego śladami, otrzymali nagrodę wiecznego przebywania z Nim w chwale niebieskiej ${ }^{43}$.

Myśl średniowiecznych minorytów zostanie utrwalona i poszerzona w programach ideowych kościołów franciszkańskich w kolejnych wiekach.

\section{KOŚCIÓE FRANCISZKAŃSKI - PRZESTRZEŃ DLA WIERNYCH I WSPÓLNOTY KLASZTORNEJ}

Już w XIII wieku świątynie minorytów skupiają licznych wiernych, którzy ze względu na kaznodziejstwo i poziom sprawowanej liturgii chętniej modlą się w kościołach mendykantów niż w parafialnych. Brat Salimbene de Adam w swojej kronice opisuje zaistniałą sytuację: „Nie jest naszą intencją ani winą, czy wierni przychodzą czy nie, naszym obowiązkiem jest zawsze to, aby odprawiać uroczyście ze śpiewem Boski kult, ponieważ nasza Reguła nakazuje nam sprawować liturgię według obrządku świętego Kościoła rzymskiego"44. Miejsca zajmowane przez franciszkanów stają się centrami duszpasterskimi, otwartymi na potrzeby ludu.

Duchowość franciszkańska skupiona na tajemnicy wcielenia, ukrzyżowanym Zbawicielu, Maryi Dziewicy i wielkich świętych zakonu, takich jak Franciszek, Antoni i Klara, spotkała się z wielką otwartością wiernych. Kościoły minorytów zaczynają się zapełniać licznymi ołtarzami, przy których oddaje się cześć Chrystusowi, Maryi oraz świętym franciszkańskim. Wiele świątyń staje się miejscami szczególnego kultu relikwii i ważnymi sanktuariami, z Asyżem i Padwą na czele. Uroczyście sprawowana liturgia oraz dynamicznie rozwijająca się pobożność prowadziła do rozparcelowania stosunkowo jednorodnej przestrzeni na nawy, miejsca szczególnego kultu, osobne kameralne części kościoła, gdzie bractwa i poszczególni wierni mogli

\footnotetext{
42 Wczesne źródła franciszkańskie potwierdzają u św. Franciszka dostrzeganie uczestnictwa Maryi w dziele Chrystusa. Widząc ubogiego Zbawiciela, dostrzega obok Niego „ubogą Panią”. Por. G. Iammarone, Duchowość franciszkańska, Kraków I998, s. II7.

43 Por. G. Iammarone, Duchowość franciszkańska, dz. cyt., s. 89.

44 Salimbene de Adam, Cronica, nuova edizione critica a cura di G. Scalia, vol. 2, Bari 1966, s. 6I6 [thum. własne].
} 
organizować swoje nabożeństwa. Przykładami takich zmian opartych na nieregularności i braku symetrii są plany kościołów franciszkańskich na terenie Niemiec, Anglii czy Skandynawii ${ }^{45}$.

Wpływ duchowości zakonu i pobożności wiernych prowadziły w konsekwencji do powstawania bocznych kaplic, fundowanych przez dobrodziejów, gdzie zakonnicy na rzecz fundatorów sprawowali msze i otaczali ich pasterską troską ${ }^{46}$.

Wewnętrzna struktura minoryckich kościołów zostaje wbogacona o miejsca pochówku możnowładców. Z tej racji chóry zakonne, krużganki klasztorne oraz przyległe kaplice zostają zaopatrzone w krypty. Franciszkanie, zależni finansowo od fundatorów i rad miejskich, w XV wieku całkowicie odeszli od pierwotnej surowości i prostoty w przestrzeni swoich kościołów ${ }^{47}$. Zaistniałe zmiany w przestrzeni sakralnej nie zburzyły jednak idei duchowości franciszkańskiej, która ciągle wyrażała się w specjalnych nabożeństwach ku czci męki Pańskiej, Maryi Dziewicy oraz świętych zakonu. Życie religijne w kościołach franciszkańskich toczyło się od wczesnych godzin rannych aż do zmierzchu; od liturgicznej modlitwy wspólnoty konwentualnej przez nabożeństwa ludowe do prywatnych, indywidualnych modlitw. Dzięki tej aktywności XVI-wieczne kościoły minorytów stały się ważnymi centrami życia religijnego ${ }^{48}$.

Zakon św. Franciszka w I5I7 roku uległ oficjalnemu podziałowi na Zakon Braci Mniejszych Konwentualnych i Zakon Braci Mniejszych Obserwantów. Życie dwóch autonomicznych rodzin zakonnych regulowały już własne konstytucje. Bracia konwentualni wypracowali jeszcze w XVI wieku trzy redakcje własnych konstytucji, jednak dopiero konstytucje zatwierdzone przez Urbana VIII w I628 roku wyznaczyły na przeszło trzy stulecia styl życia braci zamieszkujących duże konwenty. Surowy system dyscyplinarny i ściśle ułożony program życia klasztornego przyczyniły się do silnego ożywienia zakonu ${ }^{49}$.

Wśród licznych przepisów, znaczna część dokumentu określa zasady życia liturgicznego wspólnoty konwentualnej. Ponadto konstytucje zajmują się

\footnotetext{
45 Por. M. Kutzner, Architektura ..., dz. cyt., s. 29.

46 Duża liczba kapłanów zakonnych zapewniała fundatorom możliwość sprawowania tego typu mszy, a klasztorowi odpowiednie dochody. Pierwsze świadectwa o takich fundacjach znajdujemy już w XI wieku. Por. S. Koperek, Rys historyczny rozwoju liturgii mszalnej, w: Misterium Christi, red. W. Świerzawski, Kraków I993, s. 57.

47 Por. M. Kutzner, Architektura ..., dz. cyt., s. 35.

${ }^{4}$ Por. M. Kutzner, Architektura..., dz. cyt., s. 44.

49 Por. W. Di Fonzo, J. Odoardi, A. Pompei, Bracia mniejsi konwentualni..., dz. cyt., s. IIo.
} 
przestrzenią kościołów, do której zaliczają zakrystie, kaplice, oratoria, ołtarze i obrazy. W rozdziale III konstytucje wyszczególniają miejsca przeznaczone do kultu relikwii. Dokument wymaga pewności co do ich autentyczności, a także przygotowania odpowiedniego, bezpiecznego miejsca, zwanego $\mathrm{Sa}$ crarium $^{50}$, gdzie mogły być przechowywane, „, nawet przy zapalonej lampce”รI. Ołtarze w kościołach miały być zbudowane we właściwych proporcjach i odpowiednich odległościach od siebie, by ich usytuowanie sprzyjało pobożności i podkreślało świętość tych miejsc ${ }^{52}$. W przepisach liturgicznych nie znajdujemy szczegółowych informacji o dedykacji poszczególnych ołtarzy, ale na podstawie rozdziału De Processionibus należy przyjąć, że istniała pewna reguła, według której ustalano przeznaczenie ołtarzy bocznych. Obrzędy procesyjne celebrowane w poszczególne dni obejmowały ołtarze: Krzyża Świętego, Najświętszej Maryi Dziewicy i św. Franciszka ${ }^{53}$. Staje się więc pewne, że ową regułą kształtującą przestrzeń kościołów franciszkańskich w XVII wieku była duchowość zakonu, nakreślona już okresie średniowiecza.

Konstytucje Urbańskie nie narzucają treści kaplic czy ołtarzy, jednak wyrażają troskę o poprawność historyczną i teologiczną wizerunków umieszczanych w ołtarzach, przestrzegając przy tym przed jakąkolwiek niestosownością w malarstwie: „Imagines, quae praeferitim in altaribus collocantur, conformes historicae veritati sint, nilque in eis profanum, nihilque inhonestum appareat, neve procaci venustate, aut lasciua pingatur ex Decreto Concilii Tridentini'”54. Powyższy zapis nie ogranicza idei obrazów umieszczonych w ołtarzach jedynie do tematyki związanej z duchowością zakonu, ale zakłada różnorodność

5o Słowo Sacrarium miało w historii różne znaczenia: oznaczało miejsce przechowywania świętych przedmiotów, kaplicę lub zagłębienie za ołtarzem i chrzcielnicą służące do wylewania wody po ablucjach oraz zsypywania popiołu ze spalonych przedmiotów uprzednio poświęconych. Por. A. Jougan, Słownik kościelny łacińsko-polski, Poznań I958, s. 598.

${ }^{5}$ „Statuitur insuper, ne ullae inposterum Sanctorum reliquiae cum allis collocentur seu publice exponantur ad venerationem nisi de illis authentica fides habetur quam superior recognoscere, et si legitima fuerit, approbare insuper teneatur. Reliquae deinque omnes vel in sacrario aut in ecclesia aliquo tuto loco qua decet reverentia et si commode fieri poterit accendo etiam lampade custodiantur" (Constitutiones Urbanae Fratrum Ordinis Minorum Conventualium S. Francisci, Anno Domini MDCXXVIII. Xero, Essen I993, APF (OFMConv) w Krakowie, s. 88).

${ }^{52}$,Altaria vero ipsa decenti adeo proportione construantur, constructam que (quantum fieri potest) ita resarciantur, vel renovetur ut neque nimium proxima, nimiumue distantiaa sint, sed debita dispositione sic inter se composita ut ad devotionem et sanctitatem inducant" (Constitutiones Urbanae..., Anno Domini MDCXXVIII..., dz. cyt., s. 89).

53 Por. Constitutiones Urbanae..., Anno Domini MDCXXVIII..., dz. cyt., s. I02-I03.

54 Constitutiones Urbanae..., Anno Domini MDCXXVIII..., dz. cyt., s. 87. 
w treści ich przesłania. Struktura minoryckich świątyń zostaje więc otwarta na potrzeby ludu i różnego typu pobożność lokalną.

Charakterystyczna dla zakonu św. Franciszka troska obejmująca wszystko, co jest przeznaczone do kultu Bożego, ponownie została utrwalona i nakazana braciom w zapisie: „Superior quicunque localis praecipuam adhibeat diligentiam, ut Ecclesiae in suis structuris conserventur, et quando fuerit opus, sedulo reparentur. Sacella omnia tecta, mundaque sint, ipsum Ecclesiae pavimentum eiusque parietes saepius diligenter mundentur, nihilque relinquatur, quod domum Dei vel minimum immundam reddat, et inornatam, libris, vasibus, candelabris, candelis, aliisque omnibus necessaris iuxta temporum, locorum que exigentiam nullo modo carere permittat" ${ }^{\prime 5}$.

Istotnymi dokumentami regulującymi życie liturgiczne minorytów były, oprócz konstytucji, ceremoniały zakonne, opracowywane w kolejnych stuleciach ${ }^{56}$. Ceremoniał Zakonu Braci Mniejszych Konwentualnych, wydany w I632 roku, po opublikowaniu pierwszego wydania Konstytucji Urbańskich, potwierdza zawarte $\mathrm{w}$ nich postanowienia oraz podaje cenne informacje o przestrzeni franciszkańskich świątyń w XVII wieku.

Księga między innymi nakazuje, by ołtarze wielkie posiadały trzy stopnie, oraz podaje szczegółowe przepisy budowy ołtarzy bocznych. Miejsca sprawowania Eucharystii mają być zaopatrzone w krzyże i kandelabry. Przepisy zawarte w ceremoniale wyrażają głęboką troskę o bezpieczeństwo przechowywania Najświętszego Sakramentu - należy go strzec w zamkniętym tabernakulum. Miejscem przechowywania Eucharystii był ołtarz wielki, tabernakulum miało być wykonane ze srebra, pozłoconego spiżu, marmuru lub innego kosztownego materiału. Ceremoniał nakazuje, by tabernakula były przyozdobione w wyobrażenia związane z męką Pańską, oraz wspomina o konopeach okrywających miejsca przechowywania Najświętszego Sakramentu. Ponadto wśród licznych przepisów znajdują się instrukcje odnoszące się do obrusów ołtarzowych, nakryć oraz wszelkich paramentów liturgicznych. Dokument jest cennym świadectwem istnienia w kościołach franciszkańskich XVII wieku organów, których zasady użytkowania są zapisane w XIV rozdziale IV części ceremoniału ${ }^{57}$.

\footnotetext{
55 Constitutiones Urbanae..., Anno Domini MDCXXVIII..., dz. cyt., s. 86.

56 Por. F. Costa, Presenza..., dz. cyt., s. 385-386.

57 Por. Caeremonialis ordo Romanus ad usum fratrum Minorum Conventualium Sancti Francisci, I632, Biblioteca della Provincia romana, Convento di S. Francesco alla Rocca, Viterbo, s. I, I68-I75.
} 
Rozdział XVIII opisuje przebieg procesji do ołtarzy: Najświętszego Krzyża, Maryi Dziewicy i św. Franciszka. Znamienna jest wzmianka o ołtarzu Świętego Poczęcia Najświętszej Maryi Panny ${ }^{58}$, które utrwalone w zakonie jako święto zyskiwało coraz większą popularność w Kościele powszechnym ${ }^{59}$. Zwyczajowo procesje rozpoczynały się w chórze zakonnym po mszy, nieszporach lub komplecie ${ }^{60}$. Bracia $\mathrm{w}$ odpowiednim porządku udawali się przy śpiewie hymnu do poszczególnych ołtarzy, gdzie zanoszone były właściwe dla danej procesji modlitwy, responsoria i błogosławieństwa. Celebracje miały miejsce w wyznaczone dni tygodnia. Procesję Bractwa Paska św. Franciszka organizowano w wybrane niedziele miesiąca ${ }^{61}$, do ołtarza Chrystusa Ukrzyżowanego udawano się w piątki ${ }^{62}$, a do ołtarza Najświętszej Maryi

${ }_{58}$ „Praeterea in multis Ecclesis immediate post vesperas, die Dominico solet processio fieri per ecclesiam ad aliqua altaria devotionis causa, nempe ad Altare Sanctissime Conceptionis vel ad altare divi Francisci recitando hymnum Decus Morum vel Ave Maris Stella et in hoc pariter consuetudo ut supra servanda terit" (Caeremonialis ordo Romanus... I632, dz. cyt., s. I8I).

59 Święto Poczęcia Najświętszej Maryi Panny znane było na Wschodzie już od końca VII wieku. Kościół zachodni celebrował je od XII wieku, jednak w związku z tym świętem rodziły się liczne spory teologiczne. Rozwiązanie kontrowersji teologicznych wypracował franciszkański uczony bł. Jan Duns Szkot żyjący w XIV wieku. Inny franciszkanin Leonard z Nogarole w XV wieku ułożył oficjum o Niepokalanym Poczęciu Najświętszej Maryi Panny, zatwierdzone przez papieża Sykstusa IV bullą Cum praeexcelsa z I476 roku. Kolejne potwierdzenie święta miało miejsce w I483 roku, przez tego samego papieża, a było to związane z powstaniem kolejnego oficjum. Sykstus IV był zwolennikiem Niepokalanego Poczęcia ze względu na tradycję, w jakiej się wychowywał, gdyż sam był franciszkaninem. Sobór Trydencki nie rozszerzył tego święta na cały Kościół, dlatego minoryci stali się głównymi reprezentantami opcji immakulistycznej, sprawując w swoich kościołach liturgię ku czci Niepokalanego Poczęcia. Dogmat został ostatecznie ogłoszony w I854 roku. Por. K. Kowalik, Virgo Immaculata, w: Niepokalana Matka Chrystusa, red. K. Kowalik, K. Pek, Lublin 2004, s. 25-26.

60 Istnienie procesji w kościołach franciszkańskich potwierdza ks. Kamil Kantak w drugim tomie swojego dzieła Franciszkanie Polscy. Autor opisał między innymi życie liturgiczne klasztorów znajdujących się na ziemiach dawnej Rzeczpospolitej. Zob. K. Kantak, Franciszkanie polscy I5I7-I795, t. 2, Kraków I938, s. 2I2-2I3.

6r Procesję Bractwa Paska św. Franciszka celebrowano po mszy świętej lub nieszporach. W jej trakcie śpiewano hymn Decus morum, a po przyjściu do ołtarza św. Franciszka antyfonę Salve Sancte Pater. Ponadto kantorzy podejmowali werset Ora pro nobis Beate Pater Francisce, a kapłan zanosił modlitwę Deus qui Ecclesiam tuam... Obrzęd kończyło błogosławieństwo relikwiami św. Franciszka. Zob. Caeremonialis ordo Romanus..., I632, dz. cyt., s. I79.

62 Obrzęd należało urządzać w piątki w ciągu roku oprócz Wielkiego Piątku, oktawy Bożego Narodzenia i oktawy Wielkanocy. Idąc z chóru, bracia śpiewali hymn Corda Pia, po dojściu do ołtarza Ukrzyżowanego, odbywały się śpiewy wersetów, responsoriów, antyfon i oracji, należały do nich: Fratres Christus factus est pro nobis obediens, Sanctus Deus, Pater noster, 
Dziewicy w soboty. Jeśli istniał zwyczaj w niektórych kościołach, w niedziele po nieszporach wspólnota klasztorna udawała się do ołtarzy Niepokalanego Poczęcia lub św. Franciszka ${ }^{63}$.

Utrwalona tradycja procesji stała się integralną częścią służby Bożej sprawowanej w kościołach franciszkańskich. Istotny jest fakt, że bracia, organizując procesje, wychodzą poza claustrum, czyli chór. Dzięki temu przestrzeń sakralna kościołów franciszkańskich staje się wspólna dla zakonników i wiernych. Zaniknięcie przegród i lektoriów po soborze trydenckim oraz wspólny udział wiernych z franciszkanami w nabożeństwach zburzył średniowieczny silny podział pomiędzy swego rodzaju sacrum i profanum: Kościół duchowieństwa i Kościół wiernych ${ }^{64}$.

Kolejną oficjalną księgą zakonu zawierającą obrzędy liturgiczne i nabożeństwa sprawowane w kościołach franciszkańskich był Caeremonialis Ordo Romanus ad usum totuis Ordinis Minorum S. Francisci Conventualium z I759 roku. Ceremoniał zawiera przepisy Kościoła rzymskiego dostosowane do formy życia Zakonu Braci Mniejszych Konwentualnych. Księga oparta jest w znacznej mierze na wcześniejszym ceremoniale z I632 roku, jednak w swej zawartości jest o wiele bardziej precyzyjna i przekazuje więcej przepisów oraz zwyczajów ogólnokościelnych, jak również klasztornych.

Dokument, oprócz utrwalonych zwyczajów, zawiera dodatkowe przepisy związane z przestrzenią sakralną, m.in. zakazuje wieszania w chórach obrazów, które nie przedstawiają świętych postaci, oraz nakazuje, by wszelkie wyobrażenia błogosławionych umieszczane na ścianach kościołów były zatwierdzone przez Stolicę Apostolską. W przepisach ceremoniału znajduje się potwierdzenie wyposażenia franciszkańskich świątyń w konfesjonały ${ }^{65}$. Nie oznacza to, że wcześniej franciszkanie nie sprawowali sakramentu pokuty. Wręcz przeciwnie, wielu braciom powierzano obowiązki spowiedników, a konfesjonały w świątyniach minory tów były powszechne już w XVI wieku. Poświadcza ten fakt m.in. inwentarz kościoła franciszkanów w Krośnie, wedle którego w kościele tym w latach I599/I609 znajdowało się dziewięć konfesjo-

Adoramus te Christe, Jesu Christe Crucifixe. Bracia trwali w postawie klęczącej, otrzymując na koniec błogosławieństwo, po którym odmawiano Pozdrowienie anielskie. Przed udaniem się do zakrystii miała miejsce aspersja. Zob. Caeremonialis ordo Romanus..., I632, dz. cyt., s. I80.

63 Por. Caeremonialis ordo Romanus..., I632, dz. cyt., s. I76-I8I.

64 Por. M. Kutzner, Architektura ..., dz. cyt., s. 28.

65 Por. Caeremonialis Ordo Romanus ad usum totuis Ordinis Minorum S. Francisci Conventualium, I759, Biblioteca Comunale, Città di Castello, s. 515, 505. 
nałów ${ }^{66}$. Przed pojawieniem się konfesjonałów spowiadano przed ołtarzami ${ }^{67}$. Konfesjonały z biegiem lat stawały się integralną częścią przestrzeni sakralnej kościołów. Ceremoniał wyraźnie określa funkcję sacrarium, które traktowane jest w tym przypadku jako miejsce, gdzie wylewa się między innymi wodę po ablucjach, czy też używaną wcześniej podczas chrztu ${ }^{68}$.

Rozdział VI części V księgi zawiera przepisy dotyczące procesji sprawowanych w kościołach franciszkańskich - w porównaniu do wcześniejszego ceremoniału liczba tych obrzędów jest większa. Do istniejących zwyczajów dodano procesję do ołtarza św. Antoniego, która mogła odbyć się w niedzielę bezpośrednio po nieszporach ${ }^{69}$. Obrzęd jest wymieniony pośród innych możliwych celebracji, takich jak procesja do ołtarzy Niepokalanego Poczęcia ${ }^{70}$ lub św. Franciszka. Dokument nakazuje zachować istniejące zwyczaje procesyjne, które mogą istnieć w poszczególnych kościołach ${ }^{71}$. Oznacza to, że w wielu świątyniach musiały istnieć procesje do ołtarzy bocznych, zanim zostały wprowadzane do ceremoniału. Księgi publikowane przez zakon zasadniczo potwierdzały istniejące tradycje, nie wprowadzając niczego nowego, lecz zachowując je, jako odzwierciedlenie franciszkańskiego rysu w pobożności i przestrzeni sakralnej.

Ceremoniał z I759 roku ukazuje ważą różnicę w terminologii tajemnicy Niepokalanego Poczęcia Maryi. O ile księga z I632 roku mówi w tym miejscu o Sanctissimae Conceptionis, o tyle nowe wydanie z I759 roku stosuje okre-

${ }^{66}$ Por. A. Karwacki, Inwentarze i streszczenie uporzadkowanego Archiwum Konwentu OO. Franciszkanów w Krośnie, rkps, Archiwum Franciszkanów w Krośnie, s. I37.

${ }^{67}$ Przed pojawieniem się konfesjonałów spowiadano przed ołtarzami. Pojawiły się one w przestrzeni kościołów dopiero w XVI wieku. Ceremoniał rzymski z I6I4 roku nakazywał, by konfesjonały były ustawiane w widocznych miejscach i posiadały specjalną przegrodę oddzielającą spowiednika od penitenta. Por. Leksykon liturgii, dz. cyt., s. 674.

68 Por. Caeremonialis Ordo Romanus..., I759..., dz. cyt., s. 506.

69 Księga podaje śpiew responsorium $S i$ queris, który towarzyszył procesji do ołtarza św. Antoniego. Zob. Caeremonialis Ordo Romanus..., I759..., dz. cyt., s. 522.

70 Procesja ku czci Niepokalanego Poczęcia rozpoczynała się w chórze zakonnym, a kończyła przy ołtarzu Niepokalanego Poczęcia Maryi. Podczas uroczystego przejścia śpiewano hymn Ave Maris Stella lub antyfonę dostosowaną do okresu liturgicznego. Następnie po przybyciu do ołtarza i odśpiewaniu wersetu, responsorium i modlitwy odmawiano Pater noster, Ave Maria, Credo. Po tych modlitwach śpiewano Litanię do Najświętszej Maryi Panny, antyfonę Tota Pulchra wraz z wersetem i modlitwą. Na koniec miało miejsce błogosławieństwo. Zob. Caeremonialis Ordo Romanus..., I759..., dz. cyt., s. 522.

${ }^{71}$ Por. Caeremonialis Ordo Romanus..., I759..., dz. cyt., s. 522-523. 
ślenie Aram Immaculatae Conceptionis ${ }^{72}$. Ta zmiana w nazewnictwie wydaje się być efektem rozwoju kultu Niepokalanego Poczęcia Maryi w Kościele rzymskim. Spory wokół tej prawdy wiary od XVI wieku z biegiem czasu zanikały, a w 1708 roku papież Klemens XI wprowadził święto Niepokalanego Poczęcia jako obowiązkowe dla całego Kościoła ${ }^{73}$. Franciszkanie, będąc obrońcami tajemnicy Niepokalanego Poczęcia, coraz wyraźniej podkreślali tę pobożność w obrzędach procesyjnych oraz w przestrzeni swoich świątyń ${ }^{74}$.

Kościoły minorytów w epoce nowożytnej ulegały nieustannym zmianom i wpływom sztuki renesansu od XV wieku, a od XVIII w. baroku, które w swej kompozycji odbiegały od surowości gotyku ${ }^{75}$. Jednakże pomimo zmian architektonicznych Konstytucje Urbańskie zobowiązywały przełożonych do tego, by starali się zachować strukturę i styl kościołów, a gdy zajdzie potrzeba, starannie je odnawiać ${ }^{7}$. W myśl tej zasady franciszkańska koncepcja pobożności zawarta w programie świątyń minorytów pozostawała niezachwiana.

Potwierdzeniem trwałości tradycji braci mniejszych konwentualnych w przestrzeni sakralnej są badania o. Damiana Synowca OFMConv, który w swojej pracy na temat Franciszkanie polscy I722-I970 dokonał zestawienia dedykacji ołtarzy w kościołach franciszkańskich na terenie prowincji polskiej, ruskiej i litewskiej. Z jego badań wynika, że na terenach powyższych jurysdykcji najczęściej poświęcano ołtarze Chrystusowi Ukrzyżowanemu (4I), następnie Matcej Bożej, którą czczono pod różnymi wezwaniami, szczegól-

72 „Praeterea in multis Ecclesis immediate post Vesperas, die Dominico solet processio fieri per ecclesiam ad aliqua altaria devotionis causa, nempe ad Aram Immaculatae Conceptionis" (Caeremonialis Ordo Romanus..., I759..., dz. cyt., s. 522).

73 Por. C. Napiórkowski, Podstawy prawdy o Niepokalanym Poczęciu i podanie jej przez Kościót do wierzenia, w: Niepokalane Poczęcie i życie chrześcijańskie, red. D. Mastalska, Niepokalanów-Częstochowa 2005, s. I8.

74 Procesje ku czci Niepokalanego Poczęcia na przełomie wieków XVII i XVIII stały się na tyle popularne, że przejmowały je inne zakony. Do takiej sytuacji doszło w Tuluzie, gdzie dominikanie, na wzór franciszkanów podjęli inicjatywę tego typu procesji, co spotkało się ze sprzeciwem minorytów. Problem rozwiązała sama Kongregacja Rytów, zakazując braciom kaznodziejom sprawowania takich procesji. Por. J. Domański, Niepokalane Poczęcie Najświętszej Maryi Panny, w: Gratia plena. Studia teologiczne o Bogarodzicy, red. B. Przybylski, Poznań I965, s. I89-229.

75 Por. A. Nowowiejski, Wykład liturgii Kościoła, t. I, Warszawa I893, s. 2I2-2I9.

76 ,Superior quicunqe localis praecipuam adhibeat diligentiam, ut Ecclesiae in suis structuris conserventur, et quando fuerit opus, sedulo reparentur..." (Constitutiones Urbanae..., Anno Domini MDCXXVIII..., dz. cyt., s. 86). 
nie w tajemnicy Niepokalanego Poczęcia (99), kolejno św. Antoniemu (42) i św. Franciszkowi (35). Biorąc pod uwagę tylko świętych franciszkańskich, w kościołach minorytów na terenach prowincji polskiej, ruskiej i litewskiej istniało I47 ołtarzy dedykowanych świętym i błogosławionym braciom i siostrom związanych z zakonem św. Franciszka ${ }^{77}$.

\section{WNIOSKI}

Analiza przestrzeni sakralnej kościołów franciszkańskich, która została przeprowadzona w niniejszym artykule, wskazuje na ustawiczny rozwój wnętrz świątyń zajmowanych przez minorytów. Zmiany zachodzące od XIII do XVIII wieku są podyktowane ewolucją duchowości zakonu oraz potrzebami wiernych, a ich dynamikę można podzielić na trzy okresy.

Pierwsze dziesięciolecia istnienia franciszkanów to dynamiczne zmiany zachodzące wewnątrz wspólnoty, znajdujące odzwierciedlenie w przestrzeni liturgicznej. Oprócz małych kościółków i pustelni, naśladowcy św. Franciszka posiadają również duże konwenty ze zorganizowaną uroczyście liturgią. Najstarsze świadectwa liturgiczne proweniencji franciszkańskiej potwierdzają istnienie stalli, chórów oraz paramentów potrzebnych do sprawowania służby Bożej. Ten okres w historii świątyń franciszkańskich jest przede wszystkim naznaczony wysiłkami wspólnoty, skupionej na sprawowaniu kultu, przez co kościoły minorytów są gównie miejscami przeznaczonymi do modlitwy zakonników zamieszkujących dany klasztor.

Kolejnym etapem rozwojowym jest czas następujący po ogłoszeniu kościołów franciszkańskich konwentualnymi. Konsekwencją takiej decyzji papieża Innocentego IV było otwarcie się braci na laikat i duszpasterstwo. Jeszcze w XIII wieku wiele kościołów franciszkańskich staje się miejscem pochówku ówczesnych możnowładców oraz sanktuariami, w których wierni oddają cześć świętym franciszkańskim. Surowa dotychczas przestrzeń sakralna zostaje wzbogacona nowymi elementami i miejscami kultu.

Trzecim okresem kształtowania się wnętrz minoryckich świątyń jest czas współistnienia i wzajemnego oddziaływania na siebie pobożności francisz-

77 Por. D. Synowiec, Franciszkanie polscy I722-1970, w: Zakony franciszkańskie w Polsce I722-I970, red. J. Bar, Warszawa I978, s. I04-I09. 
kańskiej i ludowej. Jest to zauważalne w licznych bocznych ołtarzach, które stawiane przez dobrodziejów zakonu skupiają na sobie kult Chrystusa Ukrzyżowanego, Maryi w tajemnicy Niepokalanego Poczęcia oraz świętych franciszkańskich, szczególnie Franciszka i Antoniego z Padwy. Obrzędy procesyjne Zakonu Braci Mniejszych Konwentualnych zawarte w omawianych ceremoniałach potwierdzają wspólne uczestnictwo ludu wiernego wraz z zakonnikami zamieszkującymi poszczególne klasztory.

Zmiany zachodzące we wnętrzach franciszkańskich kościołów nie odbiegają od kierunków wyznaczanych przez Kościół, ale wydają się być odpowiedzią na potrzeby wiernych i wydawane dokumenty Stolicy Apostolskiej, które znajdowały swoje miejsce w zakonnych księgach regulujących życie liturgiczne minorytów.

Istotne jest zachowanie w przestrzeni liturgicznej pierwotnego rysu duchowości franciszkańskiej, która od średniowiecza do XVIII wieku koncentrowała się wokół Chrystusa Ukrzyżowanego, Maryi oraz świętych Franciszku i Antonim. Ponadto dzięki przepisom zawartym w ceremoniałach z I632 i 1759 roku została utrwalona pierwotna wrażliwość św. Franciszka wobec wszelkich paramentów liturgicznych oraz miejsc świętych.

Powyższa praca pozwala spojrzeć na ponad pięć stuleci formowania się przestrzeni sakralnej kościołów franciszkańskich i odkryć, jakie czynniki wpływały na jej kształt. Dzięki temu można wyznaczyć dalszy ciąg badań nad wnętrzami świątyń użytkowanych przez franciszkanów. Zbiór praktyk obrzędowych Zakonu Braci Mniejszych Konwentualnych w następnych stuleciach był utrwalany przez ceremoniał z I904 roku $^{78}$ oraz rytuał z I942 roku ${ }^{79}$. Dlatego należałoby zbadać przestrzeń liturgiczną pod kątem tych źródeł. Jakie praktyki zachowano, a z których zrezygnowano? Czy franciszkański rys duchowości w powyższych księgach został zachowany i o jakie obrzędy zostały wzbogacone zwyczaje franciszkanów?

Praca naukowa nad przestrzenią franciszkańskich kościołów w kontekście tradycji obrzędowych Zakonu Braci Mniejszych Konwentualnych może przyczynić się od odkrycia właściwego sensu zagospodarowania obecnych wnętrz minoryckich świątyń, jak również dać impuls do przywrócenia niektórych utraconych zwyczajów.

${ }_{78}$ Caeremonialis ordo Romanus ad usum totius seraphici ordinis Minorum s. Francisci conventualium, Romae 1904, Biblioteca Fra' Landolfo Caracciolo dei Frati Minori Conventuali, Napoli.

79 Zob. Rituale Romano-Seraphicum Ordinis Fratrum Minorum Conventualium, Romae 1942, Biblioteka Franciszkanów w Krakowie. 


\section{Bibliografia}

\section{Źródła rękopiśmienne}

Karwacki A., Inwentarze i streszczenie uporzadkowanego Archiwum Konwentu OO. Franciszkanów w Krośnie, rkps, Archiwum Franciszkanów w Krośnie.

\section{Źródła drukowane}

Brat Tomasz z Celano, Życiorys drugi Świętego Franciszka z Asyżu, w: Źródta franciszkańskie: Pisma Świętego Franciszka. Źródła biograficzne Świętego Franciszka, Pisma Świętej Klary i źródła biograficzne. Teksty ustalające normy dla braci i sióstr od pokuty, red. R. Prajs, Z. Kijas, Kraków 2005, s. 55I-730.

Caeremonialis ordo Romanus ad usum fratrum Minorum Conventualium Sancti Francisci, I632, Biblioteca della Provincia romana, Convento di S. Francesco alla Rocca, Viterbo.

Caeremonialis Ordo Romanus ad usum totuis Ordinis Minorum S. Francisci Conventualium, I759, Biblioteca Comunale, Città di Castello.

Caeremonialis ordo Romanus ad usum totius seraphici ordinis Minorum s. Francisci conventualium, Romae 1904, Biblioteca Fra' Landolfo Caracciolo dei Frati Minori Conventuali, Napoli.

Constitutiones Urbanae Fratrum Ordinis Minorum Conventualium S. Francisci, Anno Domini MDCXXVIII. Xero, Essen I993, APF (OFMConv) w Krakowie.

List skierowany do catego Zakonu, w: Pisma św. Franciszka i św. Klary, thum. o. K. Ambrożkiewicz, red. M. Macioszek, E. Szelachowski, P. Brzozowska, Warszawa 1992, s. 97-I02.

Oficjum o Męce Pańskiej, w: Pisma św. Franciszka i św. Klary, Testament, tłum. o. K. Ambrożkiewicz, red. M. Macioszek, E. Szelachowski, P. Brzozowska, Warszawa 1992, s. 134-150.

List do kustoszów (I), w: Pisma św. Franciszka i św. Klary, thum. o. K. Ambrożkiewicz, red. M. Macioszek, E. Szelachowski, P. Brzozowska, Warszawa 1992, s. I06-I07.

Relacja Trzech Towarzyszy, w: Źródła franciszkańskie: Pisma Świętego Franciszka. Źródta biograficzne Świętego Franciszka. Pisma Świętej Klary 
i źródta biograficzne. Teksty ustalajace normy dla braci i sióstr od pokuty, red. R. Prajs, Z. Kijas, Kraków 2005, s. I435-I505.

Rituale Romano-Seraphicum Ordinis Fratrum Minorum Conventualium, Romae 1942, Biblioteka Franciszkanów w Krakowie.

Salimbene de Adam, Cronica, nuova edizione critica a cura di G. Scalia, vol. 2, Bari 1966.

Sobór Laterański IV, w: Dokumenty soborów powszechnych, t. 2, oprac. A. Baron, H. Pietras, Kraków 2003.

Statuta generalia Ordinis edita in Capitulis generalibus celebratis Narbonae an. I260, Assisi an. I279, atque Parisiis an. I292, ed. M. Bihl, Archivim Franciscanum Historicum 34 (194I).

Testament, w: Pisma św. Franciszka i św. Klary, tłum. o. K. Ambrożkiewicz, red. M. Macioszek, E. Szelachowski, P. Brzozowska, Warszawa I992, s. $67-70$.

\section{Opracowania}

Costa F., Presenza dei Minori Conventuali nella liturgia, w: Impegno ecclesiale dei Frati Minori Conventuali nella cultura ieri e oggi (I209-1997), a cura di F. Costa, Roma I998, s. 442-445.

Di Fonzo W., Odoardi J., Pompei A., Bracia mniejsi konwentualni. Historia $i$ życie I209-1976, Niepokalanów 1988.

Domański J., Niepokalane Poczęcie Najświętszej Maryi Panny, w: Gratia plena. Studia teologiczne o Bogarodzicy, red. B. Przybylski, Poznań I965, S. 189-229.

Forstner D., Świat symboliki chrześcijańskiej, Warszawa 1990.

Iammarone G., Duchowość franciszkańska, Kraków 1998

Iriarte L., Historia franciszkanizmu, Kraków 1998.

Jougan A., Stownik Kościelny tacińsko-polski, Poznań 1958.

Kantak K., Franciszkanie Polscy I5I7-I795, t. 2, Kraków I938.

Kaproń K., Antiphoniarium Archivi s. Rufini, Assisi, Codex 5, Città del Vaticano 2009.

Koperek S., Rys historyczny rozwoju liturgii mszalnej, w: Misterium Christi, red. W. Świerzawski, Kraków I993 s. 37-78.

Kowalik K., Virgo Immaculata, w: Niepokalana Matka Chrystusa, red. K. Kowalik, K. Pek, Lublin 2004, s. 9-26.

Kunzler M., Liturgia Kościoła, Poznań 1995. 
Kutzner M., Architektura średniowiecznych klasztorów i kościołów franciszkańskich w Polsce, „Acta Universitatis Nicolai Copernici. Zabytkoznawstwo i Konserwatorstwo I3. Nauki Humanistyczno-Społeczne" I989 z. I76, s. $4-47$.

Leksykon liturgii, oprac. B. Nadolski, Poznań 2005.

Lomabrdo P., Passarelli G., Ara Coeli: la basilica e il convento: dal XVI al $X X$ secolo attraverso le stampe del fondo della postulazione della Provincia romana dei frati minori, Roma 2003.

Manselli R., Pierwsze stulecie historii franciszkanów, thum. K. Kubis, Kraków 2006.

Mazurkiewicz R., Deesis, Kraków 1994.

Napiórkowski C., Podstawy prawdy o Niepokalanym Poczęciu i podanie jej przez Kościót do wierzenia, w: Niepokalane Poczęcie i życie chrześcijańskie, red. D. Mastalska, Niepokalanów-Częstochowa 2005, s. I7-4I.

Norel J., Liturgiczna modlitwa godzin we wczesnej tradycji franciszkańskiej, w: Modlitwa franciszkańska, red. C. Napiórkowski, W. Koc, Niepokalanów 200I, s. 293-36r.

Nowowiejski A., Wyktad liturgii Kościoła, t. I, Warszawa I893.

Pikulik J., Franciszkanie nosicielami laterańskiej tradycji liturgiczno-muzycznej, „Studia Theologica Varsaviensia” 25 (I987) nr I, s. 5-I4.

Schenkluhn W., Architettura degli Ordini Mendicanti, Padova 2003.

Superson J., Oltarz, krzyż i kierunek zanoszonych modlitw, Kraków 2014.

Superson J., Wersety psalmiczne $w$, preces” godzin kanonicznych, Tyniec 2016.

Synowiec D., Franciszkanie polscy I722-I970, w: Zakony franciszkańskie w Polsce I722-1970, red. J. Bar, Warszawa 1978, s. 5-I33.

Szyma M., In ecclesia sancti Francisci in chori medio. Wprowadzenie do badań nad miejscem chóru liturgicznego w kościołach średniowiecznego Krakowa, w: Średniowieczna architektura sakralna $w$ Polsce $w$ świetle najnowszych badań, red. T. Janiak, D. Stryniak, Gniezno 20I4, s. 265-282. Szymański A., Św. Franciszek a krzyż, w: Franciszkowa droga, red. J. Bar, Warszawa I982, s. 20I-206.

Van Dijk S. J. P., Sources of the Modern Roman Liturgy. The Ordinals by Haymo of Faverscham and Related Documents (I243-I307), t. 2, Leiden I963. 


\section{Literatura pomocnicza}

Anzulewicz P., Spiritualità dei Francescani Conventuali, dimensione storica, w: Impegno Ecclesiale dei Frati Minori Conventuali nella cultura ieri e oggi (I209-1997), a cura di F. Costa, Roma I998, s. 399-420.

Grzybowski A., Zagadnienie dtugich chórów kościołów mendykanckich w Europie środkowo-wschodniej w XIII w., w: Zakony franciszkańskie w Polsce, t. I, red. J. Kłoczowski, Lublin I982, s. 227-247.

La Barbera Bellia S., Iconografia del Christo in croce nell'opera di uno scultore francescano della controriforma: fra Umile da Petralia, „Schede Medievali" I2-I3 (1987), s. 393-402.

Norel J., Graduat franciszkański z Płocka, Kraków 2005.

Paczóski M., Corda Pia. Nabożeństwo franciszkańskie - historia, teologia, duchowość, w: Modlitwa franciszkańska, red. C. Napiórkowski, W. Koca, Niepokalanów 200I, s. 393-395.

Rosenbaiger K. S., Dzieje Kościoła O.O. Franciszkanów w Krakowie w wiekach średnich, Kraków 1933.

Sczanecki P., Z dziejów uroczystości św. Franciszka w Polsce, „Studia Franciszkańskie" I (I984), s. 285-294.

Skibiński S., Pierwotny kościół franciszkanów w Krakowie, Poznań 1977.

Tomkowicz S., Średniowieczna nawa główna i nawa boczna w kościele Franciszkanów w Krakowie. Sprawozdania Komisji do Badań Historii Sztuki w Polsce, t. 8, Kraków I9I2.

Van Dijk S. J. P., Wolker J. H., The Originis of the Modern Roman Liturgy, London 1960.

\section{SUMMARY}

\section{Development of liturgical space in Franciscan churches between $13^{\text {th }}$ and $18^{\text {th }}$ centuries}

The aim of this writing is to show changes which took place in sacral space of Franciscan temples. At first Friars Minor Conventual were occupying small, abandoned churches. There they found their space for prayer. However, the first generation of 
the followers of St. Francis did not possess their own sacral area. Instead, they were only its users.

Letters of the order's founder are clearly defining sensitivity connected with cult which all members of the order should possess. Therefore emerges a need of sacral space's arrangement just in the first decades of the order. Thanks to papal privileges and a demand for ceremonial celebration of liturgy, Franciscan churches are equipped with choirs, lecterns and all paraments needed. This fact is affirmed by Ordinationes (the Franciscan liturgical statutes).

The I260 Narbonne constitutions defined a plan for sacral space of Franciscan churches. It was based on order's spirituality. The crucified Saviour is put in the middle of this plan. His sacrifice is being re-lived in the mystery of the Holly Mass. Virgin Mary and Saint John the Apostle are participating in this sacrifice as representatives of the Church, while Saint Francis and Saint Anthony are representing people redempted with Christ's blood. By following Jesus, they have received a prize of His eternal companion in heavenly glory.

Simultaneously with arrangement of God's service in conventual churches, friars are becoming more open to fraternity, which determine later arrangements in space of Franciscan churches. Many churches has become places of relics worship and important shrines, with Assisi and Padua among others. Spirituality of the Order and devotion of people have led to creation of side chapels and altars which were sponsored by benefactors, who received Holly Masses, celebrated for them, and pastoral care in exchange.

The 1632 constitutions of Pope Urban the $8^{\text {th }}$ together with order's etiquette from I759 are re-affirming the original message of Franciscan temples. It is based on mysteries of salvation which are represented by the crucified Jesus Christ, the Immaculate Conception of Virgin Mary and Franciscan Saints who with their lives example have shown a way to glory. The idea of Franciscan devotion is represented in dedicated altars and ceremonial processions.

In modern age, churches of Friars Minor Conventual were constantly influenced by changes of Renaissance ( $\mathrm{I} 5^{\text {th }}$ century) and Baroque (from $\mathrm{I} 8^{\text {th }}$ century), which composition was totally different from Gothic. However, despite some architectural changes, the Franciscan idea of devotion, which was included in the plan of churches, has remained the same.

The analysis of sacral space in Franciscan churches which has been conducted in this article heads to a conclusion of constant development of Franciscan churches interiors. The changes which took place during $13^{\text {th }}$ and $18^{\text {th }}$ centuries were dictated by evolution of order's spirituality and needs of believers. 
4.4. Uniwersytet Papieski

Tf: Jana Pawta II 